\begin{tabular}{lc}
\hline & ANNALES \\
& UNIVERSITATIS MARIAE CURIE-SKŁODOWSKA \\
VOL. VI & LUBLIN - POLONIA \\
\hline
\end{tabular}

ISSN: 2451-0491 • e-ISSN: 2543-9340 • CC-BY 4.0 • DOI: 10.17951/en.2021.6.345-358

\title{
Peculiarities of the Semantic Component of Communication Activities in Preschoolers with Developmental Delay
}

\section{Cechy semantycznego komponentu aktywności komunikacyjnej u przedszkolaków z opóźnieniem rozwojowym}

\author{
Iryna Omelchenko \\ National Academy of Educational Sciences of Ukraine \\ Mykola Yarmachenko Institute of Special Pedagogy and Psychology \\ 9, M. Berlinskoho Str., Kyiv, Ukraine, 04060 \\ iraomel210781@ukr.net \\ http://orcid.org/0000-0003-2021-7453
}

\begin{abstract}
Abstrakt. W artykule analizie poddano cechy badania semantycznego komponentu aktywności komunikacyjnej przedszkolaków z opóźnieniem rozwojowym. Ustalono, że wprowadzenie do działania komunikacyjnego stosunku emocjonalnego do rozmówcy wraz ze zrozumieniem znaczenia tworzonych komunikatów powoduje przejście na semantyczny poziom komunikacji. Udowodniono teoretycznie i eksperymentalnie, że poziom ten zakłada, iż podmiot interakcji jest w stanie wyrażać postawy emocjonalne wobec partnerów oraz interpretować i rozumieć ich stany psychiczne, co z kolei przyczynia się do zrozumienia każdego wydarzenia lub sytuacji społeczno-komunikacyjnej. Aby sprawdzić poziom semantyczny (komponent) działań komunikacyjnych, badaniu poddano mentalizację ukrytą i jawną. Ukryta mentalizacja obejmowała dokonanie przez respondentów oceny właściwości psychicznych obiektów zaproponowanych jako partnerzy oraz rozpoznanie przez nich emocji i psychicznych przyczyn tych emocji w sytuacjach społeczno-komunikacyjnych. W przypadku jawnej mentalizacji zwrócono uwagę na umiejętność rozumienia przez respondentów przyczyn różnych zachowań na podstawie wiedzy o stanach psychicznych ludzi, a także umiejętność przewidywania zachowań innych ludzi na podstawie wiedzy o stanach psychicznych własnych i cudzych oraz umiejętność rozumienia moralnych i etycznych aspektów
\end{abstract}


zachowania innych. W wyniku przeprowadzonych badań można stwierdzić, że dzieci z upośledzonym umysłowo typem aktywności komunikacyjnej mają trudności w komunikacji, nie rozumieją przyczyn różnych zachowań, a ich poziom mentalności ukrytej i jawnej jest niski. Przejawia się to w tym, że często wchodzą one w sytuacje konfliktowe z powodu błędnych wyobrażeń na temat działań innych osób. Zidentyfikowane wzorce mechanizmu mentalizacji ukrytej i jawnej mogą stanowić podstawę dla rozwoju technologii kształtującej aktywność komunikacyjną, w szczególności jej semantycznego komponentu u przedszkolaków z opóźnieniem rozwojowym.

Słowa kluczowe: aktywność komunikacyjna; semantyczny komponent aktywności komunikacyjnej; ukryta mentalizacja; jawna mentalizacja; opóźnienie rozwojowe; przedszkolaki

\begin{abstract}
The article examines the peculiarities of the semantic component of communication activity of preschoolers with developmental delay. We have determined that an emotional attitude to an interlocutor introduced into communicative actions, together with the understood meanings of created messages, means transition to the semantic level of communication. We have theoretically and experimentally substantiated that this semantic level presupposes that an interacting subject is able to express emotional attitudes towards partners, to interpret and understand their mental states, which contribute to an understanding of any event or socio-communicative situation. To study the semantic level (component) of communication activities, we examined implicit and explicit mentalization. Implicit mentalization included the respondents' assessment of the mental properties of objects proposed as partners; recognition by them of emotions and mental causes of these emotions in socio-communicative situations. Explicit mentalization means the respondents' ability to understand causes of behaviour based on knowledge of people's mental states, the ability to predict other people's behaviour based on knowledge of their own and others' mental states, the ability to understand the moral and ethical aspects of the Other's behaviour. We have determined experimentally that children with the mentally deficient type of communication activity are characterized by difficulties in communicative prediction, misunderstanding of the causes of behaviour, low level of implicit and explicit mentalization. Hence, these children often get into conflict situations due to misconceptions about the results of their own actions or the actions of others. The identified patterns of implicit and explicit mentalization will be the basis for the technology forming communicative activity, in particular its semantic component in preschoolers with developmental delay.
\end{abstract}

Keywords: communication activities; semantic component of communication activity; implicit mentalization; explicit mentalization; developmental delay; preschoolers

\title{
INTRODUCTION
}

An emotional attitude to an interlocutor introduced into a communicative act, together with understood meanings of created messages, takes communication to the semantic level. The semantic level of communication activities presupposes an individual's ability to express emotional attitudes towards a partner in conjunction with the interpretation and understanding of his/her mental states, and thus, it contributes to an "understanding" of the meaning of any event or a social communicative situation. It is well known today that effective communication is impossible without an adequate assessment of an interlocutor's feelings. Such an 
assessment is a necessary feedback that regulates the communication process. Most conflicts arise only because of misunderstanding of partners' emotional states, or because of the inability to understand, or "feel" their intentions, desires. It is important to note that the perception of a partner is impossible without taking into account all the non-verbal manifestations of his/her behaviour.

Communicative activities from the social-cultural point of view have a noumenal-phenomenal nature (Grachev 2008). The phenomenal side is revealed through information processes that have a dichotomous character, that is, these processes determine the content of a person's inner and outer world and are triggered by the psychological mechanisms of an external and internal dialogue, contributing to mutual understanding, coordination and harmonization. The noumenal side is represented by internal communicative activities, which lead to the creation of "values-images", which then allow communicative agents to produce new meanings and values, contributing to the development of each of such agents and society as a whole. At the reflexive level, through decentration (para-social and intra-personal types of interactions), a person becomes able to put him/herself into a position of the Other and actualize his/her ability to make value-meaning definition of this Other, and hence, to determine a co-value and to achieve mutual understanding with this Other (Omelchenko 2018).

Accordingly, the purpose of the study is to reveal the main milestones of the performed research on the semantic component of communicative activities of preschoolers with developmental delay.

\section{METHODS}

The conceptual basis for understanding the semantic component in the structure of purposeful communicative activities included scientific approaches: the emotional-semantic approach (Nikolskaya 2016) and an emotional-communicative one (Vilyunas 1990), which determined the specifics of the semantic component genesis.

The theoretical methods included the formal-logical analysis of various aspects of the examined problem, logical-deductive and axiomatic methods and convergence from the abstract to the specific. The used empirical methods included: an experiment (ascertaining) with the psychological methods examining the semantic component of communicative activities: A. Ulanova's "Choice of a partner" method (2015); "Predicting the behaviour of another person" method proposed by E. Sergienko, E. Lebedeva, O. Prusakova (2009); "Understanding mental causality" method proposed by the same authors, and the method of narratives developed by N. Talanova (2011). 
Mathematical-statistical analysis included the qualitative and quantitative analysis of empirical indicators with mathematical statistics (non-parametric Mann-Whitney $U$-test to determine intergroup differences).

\section{RESULTS AND DISCUSSION}

Many studies conducted both in Ukraine and abroad were devoted to peculiarities of perception and understanding of other people, in particular their facial expressions (Bodalev 1995; Ekman 2010; Ekman and Friesen 2019; Izard 2012; Kahiani 1985; Labunskaya 1986; Logvinova 2010; Panferov 1982; etc.).

Correlations existing between emotions and meanings are understood in different ways, and that is why this issue remains debatable from the psychological point of view. The findings of different researchers created the constitutive basis for determining correlations between emotional and semantic processes (Nikolskaya 2016; Vilyunas 1990; Zotkin 2000).

M. Zotkin (2000) substantiated clearly that meanings, as a mental phenomenon, are formed in three stages. At the first stage of the meaning genesis, some situational elements and their significance are recorded. Links between situational elements are revealed and the most probable, logically consistent relationships between them are determined during the second stage; thus, it is possible to control the situation and forecast its development. At the third stage, an individual reveals his/her attitude to these elements, based on his/her needs.

Thus, we can assume that the first and second stages are correlated with the "meaning understanding" operation, and the third stage is related to a greater extent with the "meaning definition". In our opinion, the first and second stages correspond to the semantic level of communicative activities, and the third one corresponds to the reflective level of communication.

O. Nikolskaya (2016), substantiating the emotional-semantic approach to the correction of autistic children's development, noted that the affective sphere can be considered as a system of meanings that guide development. The term "semantic" emphasizes that the main task is to accumulate and comprehend a child's individual affective experiences that can support the development of his/her active and differentiated inter-subjective relationships with the environment. The word "emotional" in the name of this approach implies that the main precondition for a child's development is living together with other people and an emotional understanding of what is happening in order to build a system of inter- and intra-communications.

The views on the role of the relationships between meaning and emotion, presented in the research of V. Vilyunas (1990), are consistent with ours. 
According to the scientist, both terminological systems - emotional and semantic - describe the same psychological phenomena, and, therefore, they are largely interchangeable. The differences between them are that the concept of "emotion" is less generalized and more descriptive. The author argues that there is no clear boundary between semantic and emotional phenomena, since the emotional-communicative link is the basis of semantic formations.

To study how an individual knows him/herself and others, how knowledge about mental phenomena is accumulated, and how this knowledge is presented on the mental plane is one of the most pressing tasks for modern psychology. Mental perceptions of emotions play an important role in these studies. The central issue is not the emotions themselves, but "how people talk and what they think about emotions in everyday life" (Parkinson 1998). This scientific topic was examined in different perspectives: emotional content of mental images (Gostev 2007); the content of emotional representations (Barrett and Fossum 2001); the structures of organized knowledge about emotions (Bilkina and Lusin 2000); development of this knowledge in ontogenesis (Sergienko 2002); its use during communication (Feigenberg and Asmolov 1994); and representation of emotions at different levels of consciousness (Dorfman 1997). Despite the diversity of performed studies, there are still many open questions about mental representations of emotions.

Mentalization is an important social cognitive mechanism of communicative activities. Mentalization, or reflective functioning, is the ability to create representations of one's own mental state (emotions, thoughts, intentions, desires) and mental states of others, as well as to understand their nature and influence on behaviour. There are two types of mentalization: implicit (emotional aspect of social perception, or the simultaneous way of social information processing) and explicit (cognitive-linguistic processing of social information). The latter is actually reflexive functioning, and implicit mentalization is a largely automated process that correlates with the operational component of social cognition of the Other (Holmogorova 2016).

M. Tomasello (2014) defined social cognitions as an individual's ability to perceive other people as similar to themselves, with similar orientations and mental states. This ability allows the individual to imagine him/herself in the Other's "mental clothing", and thus he/she can learn not only in them, but also "through" them.

A key approach, being developed in foreign studies in the field of developmental psychology, is children's understanding of emotions. This approach is related to the concepts of "theory of mind" or "theory of consciousness" (Wellman and Gelman 1992). "Theory of mind" means that an individual is able to imagine how 
his/her mental life and the lives of other people flow, and, in addition, has something like a theoretical construct, a theory. This construct allows an individual to separate and classify various mental phenomena and develop causal schemes.

The ability to understand that other people are the bearers of their own knowledge, beliefs, intentions and emotions, different from ours, and, thus, the possibility of predicting their behaviour is a unique human ability that allows us to interact adequately with the Other at the semantic level of communication. A necessary condition for understanding the mental states of other people is a "mental model" formed in ontogenesis (Prusakova and Sergienko 2006).

One of the most important conditions for the formation of inter-subjective attitude is an individual's awareness of the manifestations of other people's subjectivity (their intentions, desires, feelings, etc.) and manifestations of his/her own subjectivity and the ability to reveal points of intersection (Polyakov 2014).

Well-known Italian scientists C. Sinigaglia and G. Rizzolatti (2011) have the very similar views; they consider mirror neurons, present in almost all parts of the human brain, to be a neurophysiological factor of communicative activity development. These neurons are involved in anticipating actions, recognizing emotions, empathizing with the Other. The scientists consider mirror neurons as the substrate for language functioning and the construction of models of other people's consciousness that ensure the communicative success. Understanding the Other, along with understanding one's own Self as an individual separated from others, is impossible without the participation of mirror neurons (Sinigaglia and Rizzolatti 2011).

The representatives of the system-subject approach substantiated the "theory of mind" as an internal basis of communicative activities, which, in the context of our study, directly correlates with the semantic level of communicative activities (Prusakova and Sergienko 2006; Talanova 2011; Ulanova 2015; Vilenska and Lebedeva 2014).

O. Sergienko argues that a mental model is a mental mechanism of understanding; the cycle of her research has empirically proved that psychic agency is characteristic for communicative activity of four-year old children with typical development. Six-year-old children show a better ability to take into account their subjectivity and the subjectivity of a recipient, which is associated with better developed understanding of the Other's mentality. The scientist insists that the cognitive function of subjectivity is the understanding; here a continuum of subject-subject and subject-object interactions is a communicative function, and behavioural control and complacency is a regulatory function (Sergienko 2015).

To study the semantic level (component) of communicative activities, we have put forward the task to examine implicit (assessing the mental properties of objects proposed as partners; recognizing emotions and mental causes of these 
emotions in social and communicative situations) and explicit (understanding the causes of behaviour based on knowledge on people's mental states; predicting the behaviour of others based on knowledge of their own mental states and mental states of others; understanding the ethical aspects of the Other's behaviour) mentalization. To achieve this task, we used the set of examining techniques: A. Ulanova's "Choice of a partner" method; "Predicting the behaviour of another person" method proposed by E. Sergienko, E. Lebedeva, O. Prusakova (2009); "Understanding mental causality" method proposed by the same authors; and the method of narratives developed by N. Talanova (2011).

The study sample consisted of 291 preschool children; 173 preschoolers with developmental delay (hereinafter referred to as "DD" - 85 children of middle preschool age and 88 children of senior pre-school age) and 118 preschoolers with typical psychophysical development (hereinafter referred to as "TPD" 58 children of middle preschool age and 60 children of senior preschool age).

\section{IMPLICIT MENTALIZATION}

The study of the mental properties of subjects proposed as partners was carried out with A. Ulanova's (2015) "Choice of a partner" method.

During the examination, the experimenter told a child about a hidden gift for holiday ("revealed a secret"), thus motivation was created not to tell other people about it. Then, the experimenter asked the question: "Choose to whom we can entrust our secret, who will probably not reveal it to anyone?". The child was offered the following objects to choose such a partner: 1) a toy ball (as an object devoid of any living signs); 2) a teddy bear (an object that is a model of a living being); 3) a boy (a real social partner). The verbal instructions were supported by the corresponding images of the communication partners on cards.

Thus, during performing the above task, preschoolers chose a communication partner, demonstrating mental states that they attributed to it. Accordingly, the choice of non-living partners correlated as a trend to understanding wrong opinions. Children who better understood another person's ability to have their own opinions and intentions, more often chose a non-living partner, as it did not have mentality, so this solution was right.

The DD and TPD middle-preschool-age children chose significantly more often a boy as a significant partner $(\mathrm{U}=157 ; \mathrm{p} \leq 0.05)$. The children in this group mostly rejected a toy ball and a teddy bear as possible partners and actually chose a boy (92.9\% of the DD children and $53.4 \%$ of the TPD children, respectively), whereas a teddy bear and a ball were chosen by $4.7 \%$ and $2.4 \%$ of the DD children, respectively. As for the group of the TPD middle-preschool-age children, only 
$19 \%$ of them preferred a toy ball, and $27.6 \%$ a teddy bear, and, accordingly, the majority of TPD pre-schoolers decided to confide to a boy (53.4\%).

The DD senior preschoolers showed a tendency to the other "pole" of partnership (19\% chose a toy ball, $27.6 \%$ chose a toy bear), but the boy remained the predominant communication partner (59.1\% of the children). And only TPD senior preschoolers preferred a teddy bear and a toy ball $(43.4 \%$ and $33.3 \%)$ as a partner, whereas only $23.3 \%$ of them chose a boy.

The studied TPD senior preschoolers better understood other people's ability to have their own opinions and intentions, so they more often chose non-living partners, because the absence of mentality was the right solution. At the same time, the correlation between a boy chosen as a partner and the understanding wrong opinions is significantly negative $(r=-0.367 ; p \leq 0.05)$. A boy, as a human, may have his own desires and intentions, so he is not a right choice as a partner to keep the "secret". Children who coped well with the task to understand the wrong idea were able to take into account the mentality of a living partner, predict his actions, so they chose a boy much less often. This was also supported by the negative correlation between understanding the difference between the movement causes of physical and social objects and the choice of a boy as a partner $(r=-0.389$; $\mathrm{p} \leq 0.01$ ). The better the children assessed the ability of living and non-living objects to move, the less often they chose the living partner, because they understood the boy's differences from other physical objects. Physical causes of events were negatively correlated with the choice of a boy $(r=-0.443 ; \mathrm{p} \leq 0.01)$, did positively with the choice of a teddy bear $(\mathrm{r}=0.308 ; \mathrm{p} \leq 0.05)$ and had a weak correlation, as a trend, with the choice of a toy ball $(r=0.287 ; p=0.05)$. The significant differences were found between the groups of DD and TPD middle-preschool-age children as for assessing by them the mental properties of objects, proposed as partners $\left(\mathrm{U}_{\text {emp }}=1485.500 ; \mathrm{p}=0.000\right)$ as well as between the groups of DD and TPD senior-preschool-age children $\left(\mathrm{U}_{\text {emp }}=1704.000 ; \mathrm{p}=0.000\right)$.

\section{The method of narratives proposed by N. Talanova (2011)}

This method allows assessing children's ability to recognize emotions and mental causes of these emotions in situations of social communicative interactions based on the story (verbal description of the situation).

The experimenter asked children to listen to the stories and asked questions related to understanding their content. For this purpose, 3 narratives were used, which reflect typical situations of children's social interactions: a child's interaction with another child, a child's interaction with the parents, and a child's interaction with an adult (a stranger). 
The study results showed that the most complete and correct answers were given by children of the senior preschool age ( $4.6 \%$ and $51.7 \%$ of the DD and TPD children, accordingly). The middle-preschool-age children were characterized by simple division of emotions into positive and negative; in our case, the children were able to identify correctly the characters' emotions, but the children aged 4-5 years mostly called physical states and could not explain the causes of emotions (61.2\% and 48.3\% in the DD and TPD children, accordingly). The ideas on emotions of the characters from the story no. 2 (a child's interaction with a close adult) and the story no. 3 (a child's interaction with an adult) also did not cause any difficulties. The most common answers of children to the tasks related to the understanding of emotions were: "good", "fun", or "I do not know". Children had greater difficulty in substantiating these emotions but many TPD children of the senior preschool age (51.7\%) could already name the cause or explain certain emotion. Five- to seven-year-old children gave the following answers: "cheerful mood", "joyful" as an explanation of emotions, for example: "The girl was sad because her mother did not come for her", “...sad because she really wanted her mom”.

The significant differences were found between the groups of DD and TPD middle-preschool-age children as for recognition of emotions and mental causes of these emotions in the situation of communicative interaction of a child with another child $\left(\mathrm{U}_{\text {emp }}=1559.500 ; \mathrm{p}=0.000\right)$ as well as between the groups of DD and TPD senior-preschool-age children $\left(\mathrm{U}_{\text {emp }}=626.000 ; \mathrm{p}=0.000\right)$. The significant differences were found between the groups of DD and TPD middle-preschool-age children as for recognition of emotions and mental causes of these emotions in the situation of communicative interaction of a child with a parent $\left(\mathrm{U}_{\text {emp }}=1583.000 ; \mathrm{p}=0.000\right)$ as well as between the groups of DD and TPD senior-preschool-age children $\left(\mathrm{U}_{\text {emp }}=\right.$ 602.000; $\mathrm{p}=0.000$ ). The significant differences were found between the groups of DD and TPD middle-preschool-age children as for recognition of emotions and mental causes of these emotions in the situation of communicative interaction of a child with adults (strangers) $\left(\mathrm{U}_{\mathrm{emp}}=1544.000 ; \mathrm{p}=0.000\right)$ as well as between the groups of DD and TPD senior-preschool-age children $\left(\mathrm{U}_{\text {emp }}=605.000 ; \mathrm{p}=0.000\right)$.

\section{EXPLICIT MENTALIZATION}

\section{1. "Understanding mental causality" method proposed by E. Sergienko,} E. Lebedeva, O. Prusakova (2009)

This method was used to study children's ability to understand the causes of behaviour in social and communicative situations, based on knowledge about their own mental states and mental states of others. 
Successive pictures were used in this examining test to understand mental causality: the beginning and the result of a situation were presented, and children had to provide the cause (for example, deception).

According to this indicator, the DD middle-preschool-age children's answers were distributed as follows: $2.4 \%$ showed good understanding of the causes of the act (for example: a boy was angry at a cat because it had eaten his fish); $18.7 \%$ of the children showed incomplete understanding of the cause; $62.4 \%$ showed average understanding of the cause, they enumerated the events (ate a fish, turned over a bucket, he yelled at the cat); $16.5 \%$ of the children showed poor understanding of the causes, they could not explain any causes determined by the situation. The DD senior-preschool-age children showed some differences for this indicator, for example, only $4.5 \%$ showed good understanding of the causes; $28.4 \%$ of them manifested sufficient understanding of the causes, $52.3 \%$ of the children showed average understanding of the causes; and $14.8 \%$ had poor understanding of the causes.

At the same time, $17.3 \%$ of the TPD middle-preschool-age children and $51.7 \%$ of the TPD senior-preschool-age children manifested good understanding of the causes. Sufficient understanding of the causes was recorded in $34.5 \%$ of the TPD middle-preschool-age children, and in $46.7 \%$ of the TPD senior-preschool-age children. Average understanding of the cause was determined in $44.8 \%$ of the TPD middle-preschool-age children and $1.6 \%$ of the TPD senior-preschool-age children. Poor understanding of the causes was recorded in only $3.4 \%$ of the TPD middle-preschool-age children, and it was not detected in any TPD senior-preschool-age child.

Thus, poor understanding of mental causality and the inability to explain other people's behaviour in terms of mental states by senior-preschool-age children with developmental delay is stipulated by their underdeveloped theory of mind. The significant differences were found between the groups of DD and TPD middle-preschool-age children as for their ability to understand the causes of behaviour based on knowledge of their own mental states and mental states of others $\left(\mathrm{U}_{\text {emp }}=1523.000 ; \mathrm{p}=0.000\right)$ as well as between the groups of DD and TPD senior-preschool-age children $\left(\mathrm{U}_{\text {emp }}=576.000 ; \mathrm{p}=0.000\right)$.

\section{2. "Predicting the behaviour of another person" method proposed by}

E. Sergienko, E. Lebedeva, O. Prusakova (2009)

We used this method to assess the DD and TPD pre-schoolers' ability to predict other people's behaviour in social and communicative situations based on knowledge of their own mental states and mental states of others. 
In this method, a child must anticipate actions of characters, based on knowledge of their desires or thoughts. For example, "A boy wants to ride a hill. Where do you think he will go, to ride a hill or to a carousel?" The child must choose one option (according to the pictures) depending on the desire or an opinion of the discussed character.

According to this indicator, the DD middle-preschool-age children's answers were distributed as follows: $2.4 \%$ demonstrated a good ability to predict other people's behaviour (for example, based on the boy's desire); $18.8 \%$ of the children did not have a good enough ability to predict behaviour (they based on their desires); $63.5 \%$ demonstrated an average ability to predict behaviour, they enumerated the events (to ride on a hill, on a carousel); $15.3 \%$ of children showed a poor ability to predict, they could not predict any option for social situation development. The DD senior-preschool-age children showed a different result for this indicator, for example, only $4.6 \%$ showed a good ability to predict; $28.4 \%$ of such pre-schoolers demonstrated a sufficient ability; $53.4 \%$ showed an average ability; $13.6 \%$ had a poor ability.

At the same time, $17.3 \%$ of the TPD middle-preschool-age children and $50 \%$ of the TPD senior-preschool-age children demonstrated a good ability to predict. Sufficient prognostic ability was demonstrated by $31 \%$ of the TPD middle-preschool-age children, and by $48.3 \%$ of the TPD senior-preschool-age children. The average prognostic ability was found in $50 \%$ of the TPD middle-preschool-age children and in 1.7\% of the TPD senior-preschool-age children. The poor ability to predict was recorded in only $1.7 \%$ of the TPD middle-preschool-age children, and it was not detected in any TPD senior-preschool-age child.

The significant differences were found between the groups of DD and TPD middle-preschool-age children as for their ability to predict other people's behaviour $\left(\mathrm{U}_{\text {emp }}=1573.500 ; \mathrm{p}=0.000\right)$ as well as between the groups of DD and TPD senior-preschool-age children $\left(\mathrm{U}_{\text {emp }}=591.000 ; \mathrm{p}=0.000\right)$.

\section{CONCLUSION}

Thus, the theory of mind (mentalization mechanism) should be considered as the basis of conscious communicative activities, embodied in the system $I-$ the Other (I-Other I). In addition, it contributes to the emergence in a child of a feeling to be an agent (separation from the world; understanding by him/her the fundamental differences between the physical and social world; emergence of $I$ - the Other identical relations; the ability to learn not only from their own experience but also from the experience of others; the ability to use not only their 
own feelings, sensations, emotions, but also those belonging to other people in order to orient in the world).

Further research should focus on the development of a method shaping the communicative activity of preschoolers with developmental delay, which include a set of techniques for developing implicit and explicit mentalization.

\section{REFERENCES}

\section{Literature}

Barret, L.F., Fossum, T. (2001). Mental Representations of Affect Knowledge. Cognition and Emotion, vol. 15(3), 333-363, DOI: https://doi.org/10.1080/02699930125711.

Bodalev, A. (1995). Lichnost $i$ obshchenie [Personality and Communication]. Moskva: Mezhdunarodnaya pedagogicheskaya akademiya. (In Russian)

Bylkina, N., Lyusin, D. (2000). Razvitie predstavlenij detej ob emociyah v ontogeneze [Development of Children's Ideas about Emotions in Ontogenesis]. Voprosy psihologii, vol. 5, 59-62. (In Russian)

Dorfman, L. (1997). Emocii v iskusstve: teoreticheskie podhody i empiricheskie issledovaniya [Emotions in Art: Theoretical Approaches and Empirical Research]. Moskva: Smysl. (In Russian)

Ekman, P. (2010). Psihologiya emocij. Ya znayu, chto ty chuvstvuesh [Emotions Revealed: Recognizing Faces and Feelings to Improve Communication and Emotional Life]. Sankt-Peterburg: Piter. (In Russian)

Ekman, P., Friesen, W. (2019). Uznaj lzheca po vyrazheniyu lica [Unmasking the Face: A Guide to Recognizing Emotions from Facial Clues]. Sankt-Peterburg: Piter. (In Russian)

Fejgenberg, I., Asmolov, A. (1994). Kulturno-istoricheskaya koncepciya i vozmozhnosti ispolzovaniya neverbalnoj kommunikacii v vosstanovitelnom vospitanii lichnosti [CulturalHistorical Concept and the Possibilities for the Use of Non-Verbal Communications in the Recovery Education]. Voprosy psihologii, vol. 6, 74-79. (In Russian)

Gostev, A. (2007). Psihologiya vtorichnogo obraza [Secondary Image Psychology]. Moskva: Izd-vo «Institut psihologii RAN». (In Russian)

Grachev, V. (2008). Fenomen sociokulturnoj kommunikacii v sovremennoj hudozhestvennoj kulture: informacionno-aksiologicheskij analiz [The Phenomenon of SocialCultural Communication in the Modern Art Culture: The Informational-Axiological Analysis]. Doctoral dissertation. Kulturologiya Moskovskij gosudarstvennyj universitet kultury i iskusstv. Sankt-Peterburg. (In Russian)

Holmogorova, A.B. (2016). Znachenie kulturno-istoricheskoy teorii razvitiya psihiki L.S. Vyigotskogo dlya razrabotki sovremennyih modeley sotsialnogo poznaniya i metodov psihoterapii [The Importance of L.S. Vygotsky's Cultural-Historical Theory of Psyche Development for the Development of Modern Models of Social Cognition and Psychotherapy Methods]. Kulturno-istoricheskaya psihologiya, vol. 12(3), 58-92. (In Russian) 
Izard, C. (2012). Psihologiya emocij [The Psychology of Emotions]. Sankt-Peterburg: Piter. (In Russian)

Kahiani, S. (1985). Ekspresivnost emocij cheloveka [Expressiveness of Human Emotions]. Tbilisi: Helovneba. (In Russian)

Labunskaya V. (1986). Neverbalnoe povedenie (socialno-perceptivnyj podhod) [NonVerbal Behaviour (the Social-Perceptual Approach)]. Rostov: Izd-vo Rostovskogo un-ta. (In Russian)

Logvinova, I. (2010). Do problemy formuvannya neverbalnyx zasobiv komunikatyvnoyi diyalnosti ditej z rozladamy spektra autyzmu [On the Problem of Formation of Non-Verbal Communication Means in Children with Autism Spectrum Disorders]. Logopediya, vol. 2, 40-44. (In Russian)

Omelchenko, I. (2018). The Psychological Mechanisms for Implementation of the Reflective Component of Preschoolers' Deliberated Communicative Activities. Annales UMCS. Sectio N-Educatio Nova, no. 3, 37-48, DOI: http://dx.doi. org/10.17951/en.2018.3.37-48.

Panferov, V. (1982). Kognitivnye etalony i stereotipy vzaimopoznaniya lyudej [Cognitive Patterns and Stereotypes of People's Mutual Understanding]. Voprosy psihologii, vol. 5, 139-141. (In Russian)

Parkinson, B. (1998). What We Think about When We Think about Emotion. Cognition and Emotion, vol. 12(4), 615-624, DOI: https://doi.org/10.1080/026999398379592.

Polyakov, A.M. (2014). Subekt i simvol [A Subject and a Symbol]. Minsk: BGU. (In Russian)

Prusakova, O.V., Sergienko, E.A. (2006). Ponimanie emotsiy detmi doshkolnogo vozrasta [Understanding Emotions by Preschool Children]. Voprosy psihologii, vol. 4, 24-36. (In Russian)

Sergienko, E.A. (2002). Kognitivnoe razvitie [Cognitive Development]. In: V. Druzhinia, D. Ushakova (red.), Kognitivnaya psihologiya [Cognitive Psychology]. Moskva: PERSE. (In Russian)

Sergienko, E.A., Lebedeva, E., Prusakova, O. (2009). Model psihicheskogo kak osnova stanovleniya ponimaniya sebya i drugogo vontogeneze cheloveka [A Mental Model as the Basis for Understanding of Oneself and the Other in Human Ontogeny]. Moskva: Izd-vo «Institut psihologii RAN». (In Russian)

Sinigaglia, C., Rizzolatti, G. (2011). Through the Looking Glass: Self and Others. Consciousness and Cognition, vol. 20(1), 64-74, DOI: https://doi.org/10.1016/j. concog.2010.11.012.

Tomasello, M. (2014). A Natural History of Human Thinking. Cambridge: Harvard University Press.

Ulanova, A. (2015). Model psihicheskogo kak mentalnaya osnova vospriyatiya partnera po kommunikacii [A Mental Model as a Mental Basis for the Perception of a Communicative Partner]. Psihologicheskie issledovaniya, vol. 8(39), 9. (In Russian) Vilyunas, V.K. (1990). Psihologicheskie mehanizmyi motivatsii cheloveka [The Psychological Mechanisms of Human Motivation]. Moskva: MGU. (In Russian)

Wellman, H.M., Gelman, S.A. (1992). Cognitive Development: Foundational Theories of Core Domains. Annual Review of Psychology, vol. 43, 337-375, DOI: https://doi. org/10.1146/annurev.ps.43.020192.002005. 
Zotkin, N.V. (2000). Smyislopolaganie v situatsiyah neopredelennosti [Meaningfulness in Uncertain Situations]. An abstract of doctoral dissertation. Moskva: Psihologiya lichnosti. (In Russian)

\section{Netography}

Nikolskaya, O.S. (2016). Emotsionalno-smyislovoy podhod k korrektsii rasstroystv autisticheskogo spektra [The Emotional-Semantic Approach to the Correction of Autism Spectrum Disorders]. Almanah Instituta korrektsionnoy pedagogiki. Retrieved from: http://alldef.ru/ru/articles/almanah-26/emoczionalno-smyislovoj-podxod-k-korrekczii-rasstrojstv-autisticheskogo-spektra [access: 20.05.2020]. (In Russian)

Sergienko, E.A. (2015). Model psihicheskogo i sotsialnoe poznanie [A Mental Model and Social Cognition]. Psihologicheskie issledovaniya, vol. 8(6). Retrieved from: http://psystudy.ru/index.php/num/2015v8n42/1163-sergienko42.html [access: 20.05.2020]. (In Russian)

Talanova, N. (2011). Ponimanie doshkolnikami televizionnoj reklamy i socialnyh vzaimodejstvij [Preschoolers' Understanding of Television Advertising and Social Interactions]. Psihologicheskie issledovaniya, vol. 4(18), 9. Retrieved from: http:// psystudy.ru/index.php/num/2011n4-18/517-talanova18.html [access: 20.05.2020]. (In Russian)

Vilenskaya, G., Lebedeva, E. (2014). Razvitie ponimaniya mentalnogo mira i kontrolya povedeniya v doshkolnom vozraste [Development of Mental World Understanding and Behavioural Control at the Preschool Age]. Psihologicheskie issledovaniya, vol. 7(38). Retrieved from: http://psystudy.ru/index.php/num/2014v7n38/1064-vilenskaya38.html [access: 20.05.2020]. (In Russian) 